\title{
Production Performance of Koekoek Chickens Under Backyard Management Conditions
}

\author{
Tesfa Geleta \\ Oromia Agricultural Research Institute, Adami Tulu Research Center, Ziway, Ethiopia \\ Email address: \\ ngtesfa@gmail.com

\section{To cite this article:} \\ Tesfa Geleta. Production Performance of Koekoek Chickens Under Backyard Management Conditions. International Journal of Biomedical \\ Materials Research. Vol. 8, No. 2, 2020, pp. 25-28. doi: 10.11648/j.ijbmr.20200802.13
}

Received: October 8, 2020; Accepted: November 9, 2020; Published: December 11, 2020

\begin{abstract}
The study was conducted in East Shoa zone in Dugda district from April 2017 to June 2018 to evaluate the production performance of koekoek chickens under farmers` management conditions. A total of 193 female and 32 male three months age grower koekoek chicken were used for the study. Three months grower koekoek chickens were distributed to five farmers research extension groups (FREGs) in Dugda districts of the mid rift valley of Ethiopia. Average age at sexual maturity, annual egg production and mortality of koekoek chicken obtained under farmers management condition were $22 \pm 1.2$ weeks, $164 \pm 8.4 \mathrm{eggs} / \mathrm{hen} / \mathrm{year}$ and $31 \%$ respectively. Weight of chicken at first egg laying and weight of cockerel at 22 weeks of age were $1.6 \pm 0.4$ and $2.4 \pm 0.35 \mathrm{~kg}$ respectively. The mean value measurements obtained on egg weight in gram $(\mathrm{g})$, shell thickness in millimeter $(\mathrm{mm})$, yolk color, albumin weight in gram $(\mathrm{g})$ and yolk weight in gram $(\mathrm{g})$ were $44.28 \pm 2.96,0.62 \pm 0.16$, $6.7 \pm 0.5,27.28 \pm 3.4$ and $12.8 \pm 1.4$ respectively. In the study area the frequent existence of Newcastle disease and external parasite was found to be the bottle neck for exotic poultry production. In addition lack of adequate package delivery and supply system are among the observed problems in the study area. We can conclude that poultry production in the study area is economically feasible along with veterinary service delivery and input supply like supplementary feed.
\end{abstract}

Keywords: Farmers Research Extension Group, Mortality Rate, Egg Production, Performance, Supplementing

\section{Introduction}

The empowerment of farmers through introduction of poultry technology may contribute significantly to reducing poverty, enhancing food security, and promoting gender equality. Poultry production has a great role for poverty reduction in rural poorest society [1]. Thus, interventions which are targeting farmers are crucial towards reaching those development goals and increasing poultry production. Unfortunately, village poultry production is constrained by a low input-output production system and characterized by small size of unimproved indigenous breed. In Ethiopia the majority of chicken population composed of low producing scavenging indigenous chickens [2]. The annual egg production potential of indigenous Ethiopian chicken ranges from 40-60 with a single egg weighing between 39 and 46g [3]. The problem can be overcome through introducing, evaluating and identifying sui exotic breed that can adapt and performed under farmer condition. Identifying suitable tropically adapted poultry breeds is one of the strategies designed by Ethiopian livestock master plan to meet its chicken meat and egg demand for its growing population and produces export surpluses [4].

Koekoek chickens are one of a notable synthetic chicken breed of South African to be introduced to Ethiopia. The breed is very popular for egg and meat production [5]. The breed imported to Ethiopia because they matured at very young age, laid good number of brown shelled eggs, have excellent resistance to viral and bacterial diseases and cope with hot environmental conditions. Since chickens under rural production systems are kept both for meat and egg production [6] introduced koekoek chicken breed is the best option for small scale poultry producers. The on-station study conducted at Adami Tulu Agricultural research center (ATARC) indicated that age at first egg lay, number of eggs laid per year, and egg weight of koekoek chickens is 5 months, 213 eggs, and 51 gram respectively [7].

Considering their production traits (higher egg production and fast growing rate) they were distributed for small holder farmers to evaluate their production performance under farmers' management conditions and to satisfy the observed 
gap with better poultry breed.

\section{Materials and Methods}

\subsection{Study Area}

The study was carried out in East shoa zones in Dugda district. Dugan district is located in the central part of Rift valley. According to Dugda district Agricultural office the district lies between $7^{\circ} 58^{\prime} \mathrm{N}$ and $38^{\circ} 43^{\prime} \mathrm{E}$ and the altitude is ranges from 1600 to 2100 meters above sea level (masl) in the great rift valley of Ethiopia. The district shares boundary line with: - Bora woreda in the north and north West, Arsi in the east, Adam Tullu Jiddu Kombolicha district in the south and Southern Nation Nationalities Peoples of Ethiopia (SNNP) in the west. The annual rainfall of the district estimated to vary between $700 \mathrm{~mm}$ to $800 \mathrm{~mm}$. This is often preceded by small rainy season running from January to May. The average annual minimum and maximum temperature of the district is $15^{\circ} \mathrm{C}$ and $28^{\circ} \mathrm{C}$ respectively. Generally the area is belongs to semi-arid (drought prone) region of the country.

\subsection{Farmers Selection and Grouping (FREG Formation)}

Training on koekoek chickens management like feeding, watering, healthy care, hygiene and house construction was given for farmers in the study area and for Development agents (DAS) at farmer training center. After training participant farmers were selected in collaboration with subject matter specialist (SMS), Development agents (DAs) and with kebele leaders. Purposive sampling was used for farmer's selection depending up on their accessibility, interest to construct poultry house and to provide improved management to the distributed chickens, their willingness to contribute for some costs of inputs, to participate on community meeting, visits, trainings and to organize themselves in groups. The selected farmers were organized in to farmers' research extension (FREG) group. A total of five (5) farmers research extension groups were organized each having a group leader and secretary. Group leaders were selected based on literacy level, acceptance in the community and willingness to serve the group. Regular monitoring was done by researchers from Adami Tulu research center and by Development agents (DAs). Koekoek chicken with the ratio of 6 male to 39 female distributed for each FREGs.

Table 1. Shows FREG 's members and chickens distributed for each FREG.

\begin{tabular}{lll}
\hline FREG & FREG members & Total chickens distributed/FREG \\
\hline FREG 1 & 12 & 45 \\
FREG 2 & 12 & 45 \\
FREG 3 & 12 & 45 \\
FREG 4 & 18 & 45 \\
FREG 5 & 18 & 45 \\
\hline
\end{tabular}

*FREG= Farmer research extension group

\subsection{Animal Management}

Commercial diet composed of maize, soybean, wheat bran soybean toasted, Noug cake, salt, bone meal, limestone and premix was used during on-station rearing period. During the starter period 50 gram commercial starter ration containing $20 \% \mathrm{CP}$ and $2800 \mathrm{kcal} \mathrm{ME} / \mathrm{kg}$, was provided each chicken each day. Three plastic tube feeders and three bell shaped (round) plastic waters were used to provide feed and water ever day in brooding hay boxes. During growing period 75 gram per head per day $(\mathrm{g} / \mathrm{h} / \mathrm{d})$ growing ration containing $16 \%$ $\mathrm{CP}, 2700 \mathrm{kcal} \mathrm{ME} / \mathrm{kg}$ was provided. Six plastic tube feeders and six bell shaped (round) waters were used to provide feed and water ever day in growing house during growing period. At the age of three months chicken were distributed to farmers. During distribution one quintal commercial grower feed was given with chickens for farmers to aware the farmers to purchase commercial grower and layers feed from available area and to aware farmers to formulate balanced diet from locally available feed resources. After the distributed feed finished farmers left the chicken at the back yard and supplement with feed composed of maize, wheat, sorghum and wheat bran when the chicken return from scavenge. Water provided in house when the chicken return from outside.

\subsection{Data Collection}

Mortality and egg production were recorded daily using the data collection format developed and distributed for farmers. Body weight of the chickens at point of egg lay and body weight of cockerel were measured using suspended spring balance. At the end of the experiment ten (10) eggs from each FREG totally fifty (50) eggs from all FREG were purchased for egg quality parameters data collection. Eggs were weighed using an electronic digital balance. Egg length, egg width and egg shell thickness were measured using electronic digital caliper and yolk color was determined by adjusting the score of yolk color on color fan from Roche. Weight of Albumin was calculated as the difference between egg weight and sum of shell weight and yolk weight. Some of the Qualitative data were collected through observation and discussion with farmers.

\subsection{Data Analysis}

Data collected were analyzed using descriptive statistics and standard deviation was used to compute the variation of the mean. Some of the qualitative data were described using descriptions /narrations of the events.

\section{Results and Discussions}

Table 2. Age at first egg laying, mortality, egg production and weight of koekoek chickens under farmer management conditions.

\begin{tabular}{ll}
\hline Parameters & Mean \pm SD \\
\hline Age at first egg laying (weeks) & $22 \pm 1.20$ \\
Annual egg production /hen & $164 \pm 8.40$ \\
Weight of chicken at first egg laying $(\mathrm{kg})$ & $1.60 \pm 0.40$ \\
Weight cockerel at 22 weeks $(\mathrm{kg})$ & $2.40 \pm 0.35$ \\
Mortality $(\%)$ & 31 \\
\hline
\end{tabular}

$\mathrm{SD}=$ standard deviation, $\mathrm{kg}=$ kilogram,$\%=$ percent 
The egg production performance of koekoek chickens under farmers` management condition was lower compared to the on-station study done in the previous work. The current finding also lower than the report of Desalew Tadesse et al. [8] for the same breed done under farmers management condition most probably due to different managements (housing, feeding and hygiene) provided by farmers. Egg production performance of koekoek chickens in the current study is higher than the annual egg production performance of indigenous chicken (54.3 \pm 8.25$)$ reported by Abraham Lemlem and Yayneshet Tesfay [9]. Egg production performance of the distributed chickens declaimed as the distributed supplementary feed finished when farmers started feeding with unprocessed maize, wheat, wheat bran and sorghum because the chickens subjected to new feed that may lack an important nutrients like essential amino acid since layers premixes was not provided by farmers. This agree with the report of Buyse et al.[10] who reported that, the nutrient content of diet, nutrient composition of diet has high impact on the performance of chickens. Additionally the chickens were left around the farmers' house to find feed and it expended energy for moving rather than for production. This means egg production declined as the energy they gain declined and this agree with the report of CTA [11].

Compared to on-station study done mortality of koekoek chickens was high under farmer management condition. This is due to different management like feeding, housing and ventilation of their houses. The mortality rate of koekoek chicken in the current study is lower than the mortality rate of fayoumi $(35.3 \pm 4.5)$ reported by Abraham Lemlem and Yayneshet Tesfay [9] but similar with the 33\% mortality rate reported by Samson Leta et al. [12] for the study done under farmers management condition. Newcaste disease, fowl pox, Diarrhea and external parasite (Poultry lice and mites) were the serious disease caused poultry death in the study area. The major causes of poultry losses under farmers condition includes Newcastle disease [13] and nutritional stress [14] that agree with the current findings. Lack of hygiene and poultry house ventilation made the chickens to expose to diseases. Because of limited resource like additional poultry house for isolation farmers didn't isolated chickens attacked by parasite from others and this increased the transmission of parasite and disease and caused higher death. In general the breed did not get the management required for improved breed rearing; this caused high mortality rate and lower egg production performance.

Farmers used the egg laid for family consumption and for income generation. Especially women started local saving by the money they generated from selling of eggs. All farmers started incubation of koekoeks' chickens' eggs using local broody hens. This indicated the highest demand and acceptance of the breed because it is fast growing and good layer breed compared to the local chickens. Growth rate and egg production are economically the most important trait for Ethiopian smallholder poultry producers [6] and the production trait (egg production and fast growth) of koekoek chicken made higher acceptance among farmers.
Table 3. Showing some egg `s quality parameters of koekoek chickens.

\begin{tabular}{ll}
\hline Egg quality trait & Mean \pm SD \\
\hline Egg weight $(\mathrm{g})$ & $44.28 \pm 2.96$ \\
Egg length $(\mathrm{mm})$ & $39.17 \pm 2.48$ \\
Egg width $(\mathrm{mm})$ & $52.17 \pm 1.47$ \\
Shell thickness $(\mathrm{mm})$ & $0.62 \pm 0.16$ \\
Yolk weight $(\mathrm{g})$ & $12.8 \pm 1.4$ \\
Albumen weight $(\mathrm{g})$ & $27.28 \pm 3.4$ \\
Shell weight & $4.2 \pm 0.38$ \\
Yolk color & $6.7 \pm 0.5$ \\
\hline
\end{tabular}

$\mathrm{g}=\mathrm{gram}, \mathrm{mm}=$ millimeter,

The egg weight of koekoek chickens in the current study was lower than the on-station study done $(51.17 \pm 3.2)$ gram by Tesfa Geleta, Usman Abdulkadir [6] and than the on-farm study done (48.84 \pm 6.77$)$ gram by Desalew Tadesse et al. [8] for the same breed. Variation in egg weight most probably caused due to different feed resource because egg weight is the function of breed and protein source feed. On the other hand shell thickness and yolk color highly improved in the current on-farm study compared to the on-station study done because the chickens were exposed to green feeding around farmer's house and to scratch ground to collect minerals. This results are in line with the finding of Zaman et al.[15] who observed hens subjected to green feed gave higher internal egg qualities like higher shell thickness and higher yolk color score compared to the on-station research done. Higher shell thickness and higher yolk color reported by Tulin cicek and Ahemet Kartalkanat [16] from village eggs are also highly agree with the current finding.

\section{Conclusion and Recommendation}

Koekoek chickens are well adapted to semi-arid agroecology of mid rift valley area of Ethiopia. Since the primary poultry production in Ethiopia is for both egg and meat (fast growing) breed, it's demand is very high among farmers. The production performance of koekoek chickens declined compared to on-station study under farmers' management condition due to poor managements (lack of adequate supplementary feed and poor hygienic conditions). The production performance of koekoek chickens under back yard management condition also hindered due to inadequate veterinary service and lack of multiplying agent (source of stock replacement) and disease outbreak that caused high mortality rate.

To maintain higher egg production performance of the chickens supplementing with either commercial supplementary feed or formulating balanced feed from the available feed resource and protecting disease through providing appropriate sanitation are very important. Therefore it is necessary to establish input supply system, facility, basic poultry veterinary service, supply or establishing poultry multiplication center with the aim of supplying day-old chickens or pullet for local farmers at district level or in nearby. Since the current study addressed only adaptability and production performance it lacks economic data. Further study should be done through 
considering the amount and types of input supplied by farmers and through collecting all economic data of exotic chicken rearing under farmers condition.

\section{References}

[1] Reta D (2009). Understanding the role of indigenous chickens during the long walk to food security in Ethiopia. Livestock Research for Rural Development 21 (8): 116. Retrieved May 23, 2008, from http://www.lrrd.org/lrrd21/8/dugu21116.htm.

[2] Dawud Ibrahim (2014). Evaluation of the production performance of commercial broiler parent stock (Hubbard JV) on research station condition in Ethiopia. Ethiopian journal of Animal production. 14 (1) 15-23. Debreziet, Ethiopia.

[3] MoA (Ministry of Agriculture) (1997). National Ruminant Livestock development strategy of Ethiopia, Addis Ababa, Ethiopia.

[4] LMP (livestock master plan) (2015). Ethiopian livestock master plan. Roadmaps for growth and transformation. A contribution to the Growth and Transformation Plan II (20152020). Developed by the LMP team for the Ministry of Agriculture, Livestock Resources Development Sector. August 2015.

[5] Grobbelaar J AN (2008). Egg production potentials of four indigenous chicken breeds in South Africa. Pretoria, Tshwane University of Technology. M. Tech. Thesis.

[6] Nigussie Dana, Liesbeth H, Van der, Tadelle Dessie, Johan A M, Van Arendonk (2010). Production objectives and trait preferences of village poultry producers of Ethiopia. Implications for designing breeding schemes utilizing indigenous chicken genetic resources. Tropical Animal Health production. 2010 Oct. 42 (7); 1519-1529.

[7] Tesfa Geleta, Usman Abdulkadir (2018). Production performance evaluation of Koekoekchickens at Adami Tulu research center. African Journal of Agricultural Research. Vol. 13 (35), pp. 1852-1856, 30 August, 2018.

[8] Desalew Tadesse, Harpal Singh, Ashenafi Mengistu,
Wondimeneh Esatu, Tadelle Dessie (2013). Study on productive performances and egg quality traits of exotic chickens under villa production system in East Shewa, Ethiopia. In African Journal of Agricultural Research. Vol. 8 (13), pp. 1123-1128, 11 April, 2013.

[9] Abraham Lemlem and Yayneshet Tesfay (2010). Performance of exotic and indigenous poultry breeds managed by smallholder farmers in northern Ethiopia. Livestock Research for Rural Development 22 (7) 2010.

[10] Buyse, J., E. Decuypere, L. Bergham, E. R. Kuhn and F. Vandesande (1992). The effect of dietary protein content on episodic growth hormone secretion and on heat production of male broilers. Br. Poult. Sci., 33: 1101-1109.

[11] CTA (Center of Technical for Agriculturalist) (2001). The tropical Agriculturalist. Poultry. MACMILLAN EDUCATION LTD London and Oxford. Companies and representatives throughout the world.

[12] Samson Leta Regassa, Endalew Bekana and Tesfa Geleta (2013). Production Performance of Fayoumi Chicken Breed Under Backyard Management Condition in Mid Rift Valley of Ethiopia. Herald Journal of Agriculture and Food Science Research Vol. 2 (1), pp. 078 - 081 January, 2013.

[13] Alemu Y and Tadelle D (1998). The Status of Poultry Research and Development in Ethiopia. In: the Proceedings of the 5th Conference, Ethiopian Society of Animal Production pp. $40-60$.

[14] Chitate F and Guta M (2001). Country Report: Zimbabwe. In: Alders R G and Spradbrow P B (Editors) Proceedings of the SADC Planning Workshop on Newcastle Disease Control in Village Chicken 6-9 March 2000, Maputo, Mozambique pp 47-52.

[15] Zaman, MA, Sørensen P and Howlider MAR (2004). Egg production performances of a breed and three crossbreeds under semi-scavenging system of management. Livestock Research for Rural Development 16 (8) 2004.

[16] Tulin cicekand Ahemet kartalkanat (2009). Comparison of village eggs and commercial eggs in terms of egg quality. Journal of Animal and veterinary Advances 8 (12): 25422545, 2009. 